\title{
Study on High-Strength Ring Chain Dynamic Characteristics under Different Launch Parameters
}

\author{
Q. Zhang, J. M. Liu, Y. F. Liu, and L. Y. Li \\ College of Mechanical Engineering, Liaoning Technical University, Fuxin, China
}

УДК 539.4

\section{Оценка динамических механических характеристик высокопрочной кольцевой цепи транспортного оборудования при различных рабочих параметрах}

\author{
К. Жанг, Ж. М. Лиу, Ю. Ф. Лиу, Л. Я. Ли \\ Механико-машиностроительный колледж, Технический университет Ляонинга, Фуксин, Китай
}

Исследованы механические характеристики высокопрочной кольцевой цепи транспортного оборудования при различных рабочих параметрах и связанное с этим энергопотребление. Динамическая контактная задача моделируется с помощью конечноэлементного пакета ABAQUS для различных транспортных нагрузок и скоростей движения ичепи с последуюшей экспериментальной верификацией полученных результатов. Установлено, что оптимальное функционирование иепи соответствует скорости движения 5,65 м/мин, при которой деформация и напряжение являются стабильными. В режиме перегрузки нормальное напряжение возрастает многократно, что приводит к существенному повреждению иепи. Показано, что при холостом режиме работы цепи 23,8\% потребляемой энергии расходуется на преодоление сил трения. При увеличении рабочей нагрузки наблюдается линейный рост потребляемой энергии. Полученные динамические механические характеристики иепи позволяют уточнить прогноз ее долговечности в условиях эксплуатации и усовершенствовать схему энергопитания электромоторов.

Ключевые слова: высокопрочная кольцевая цепь, эксплуатационные характеристики, расчет энергопотребления, скорость движения цепи, транспортная нагрузка.

Introduction. High-strength ring chains are widely utilized as the hauling mechanism in transportation and lifting machineries, and because of the complicated loads generated by actual working conditions, high-strength ring chains frequently generate fracture failure, which will affect the normal operation of devices adversely and even cause serious accidents. Therefore, the scholars worldwide are paying attention to this issue. Zhang et al. analysed the dynamic characteristics and impact damage of the scraper under various working conditions and chain speeds, obtaining corresponding mechanical properties [1-3]. He et al. [4] investigated the contact characteristic between ring chains and sprocket wheel under different sorts of working condition (i.e., the full load launch, normal braking, and braking caused by the stuck ring chain based on Abaqus, achieving the longitudinal dynamics model. Mao et al. [5] designed the PID fuzzy controller of the chain tension and analysed the change laws of the chain tensions under different working conditions. Shi and Gao [6] established the mechanical model of high-strength ring chains and studied the effect of the inside width of ring chains on their mechanical properties through altering the loading frequency. The above investigations can provide certain theoretical guidance for the prediction and analysis of the operating performance of high-strength ring chains. 
However, the effect of launch parameters on the dynamic characteristics laws of ring chains is not illustrated clearly. To investigate the above issue systematically, the dynamic characteristics of ring chains under distinct launch parameters are executed in this study.

1. Establishment of Theoretical Model. The majority of metal materials exhibits both elastic and plastic deformations during the tensile process. Particularly, low-carbon steels are the typical representation of plastic materials, which has four obvious stages: the elastic stage, yield stage, hardening stage, and local necking stage. Generally, this sort of material is defined as the bilinearity or polyteny models to reflect the true stress-strain status. In addition, for the materials following Mises rule, the bilinear kinematic hardening model is utilized to cope with the minor strain and nonlinear problems of isotropic materials. For the majority of metal materials, the bilinear kinematic hardening model [7-9] is suitable for them. As discussed above, the bilinear kinematic plastic model is used in this study, as given by

$$
\sigma_{y}=\left[1+\left(\frac{\dot{\varepsilon}}{C}\right)^{1 / P}\right]\left(\sigma_{0}+\beta E_{P} \varepsilon_{P}^{e f f}\right),
$$

where $\sigma_{y}$ is the yield stress, $\sigma_{0}$ is the initial yield stress, $\dot{\varepsilon}$ is the strain ratio, $C$ and $P$ are the parameters of Cowper-Symonds strain ratio, $\varepsilon_{P}^{e f f}$ is the effective plastic strain, $\beta$ is the hardening parameter, and $E_{P}$ is the plastic hardening modulus. The plastic hardening modulus is

$$
E_{P}=\frac{E_{\text {tan }} E}{E-E_{\text {tan }}}
$$

where $E$ is the elastic modulus, and $E_{\text {tan }}$ is the tangent modulus. The tangent modulus value is $2444 \mathrm{MPa}$ [7].

$\mathrm{PRO} / \mathrm{E}$ is used to establish the 3D model of ring chains, as shown in Fig. 1. As shown in Fig. 1, there are three intact ring chains and two semi-rings. For the convenience of applying loads and boundary conditions in ABAQUS, let the ring chains at the both ends of the 3D model be semi-rings.

The chemical components of material and the corresponding mechanical properties are listed in Tables 1 and 2.

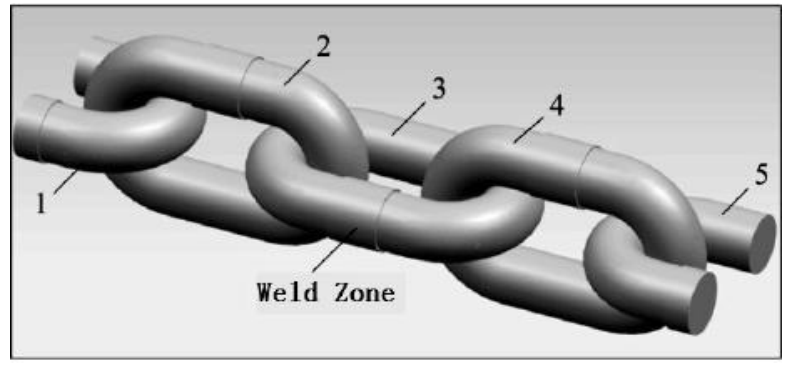

Fig. 1. 3D model of ring chains.

2. Launch Characteristics under Different Chain Speeds. To investigate the dynamic characteristics of ring chains under different chain speeds, three sorts of chain speed (i.e., 1.85, 5.6, and $7.8 \mathrm{~m} / \mathrm{min}$ ) are selected. In particular, the semi-ring 1 (see Fig. 1) with the density of $7.3 \cdot 10^{-1} \mathrm{~kg} / \mathrm{mm}^{3}$ is used to represent the stuff with the mass of 3 ton, in order to simulate the acceleration process. Through the simulation, the stresses and strains under different launch speeds are obtained, as shown in Fig. 2. 
Study on High-Strength Ring Chain Dynamic Characteristics ...

$\mathrm{T}$ a b 1 e 1

Chemical Components and Percentages of Material

\begin{tabular}{||c|c|c|c|c|c|c|c||}
\hline Component & $\mathrm{C}$ & $\mathrm{Mn}$ & $\mathrm{Si}$ & $\mathrm{S}, \mathrm{P}$ & $\mathrm{Cr}, \mathrm{Ni}$ & $\mathrm{Cu}$ & $\mathrm{Fe}$ \\
\hline Percentage (\%) & $0.07-0.24$ & $1.40-1.80$ & $0.17-0.37$ & $\leq 0.025$ & $\leq 0.30$ & $\leq 0.25$ & $\begin{array}{c}\text { Balance } \\
\text { (remain) }\end{array}$ \\
\hline
\end{tabular}

$\mathrm{T}$ a b 1 e 2

Mechanical Properties of Material

\begin{tabular}{|c|c|c|c|c|c|c|c|}
\hline \multicolumn{7}{|c|}{ Mechanical properties } & \multirow{2}{*}{$\begin{array}{c}\text { Brinell } \\
\text { hardness } \\
\text { HB } 100\end{array}$} \\
\hline $\begin{array}{c}\text { Tensile } \\
\text { stress } \\
\sigma_{b}, \\
\mathrm{MPa}\end{array}$ & $\begin{array}{l}\text { Yield } \\
\text { stress } \\
\sigma_{s} \\
\mathrm{MPa}\end{array}$ & $\begin{array}{c}\text { Percentage } \\
\text { elongation } \\
\text { after } \\
\text { fracture } \\
\sigma_{5}, \%\end{array}$ & $\begin{array}{c}\text { Percentage } \\
\text { reduction } \\
\text { of area } \\
\psi, \%\end{array}$ & $\begin{array}{c}\text { Impact } \\
\text { energy } \\
A_{k}, \mathrm{~J}\end{array}$ & $\begin{array}{c}\text { Elasticity } \\
\text { modulus } \\
E, \mathrm{MPa}\end{array}$ & $\begin{array}{c}\text { Poisson's } \\
\text { ratio } \\
\mu\end{array}$ & \\
\hline 785 & 590 & $\begin{array}{l}\text { Greater } \\
\text { or equal } \\
\text { to } 10\end{array}$ & 40 & 47 & 210000 & 0.28 & $\begin{array}{c}\text { Less } \\
\text { or equal } \\
\text { to } 187\end{array}$ \\
\hline
\end{tabular}

As shown in Fig. 2, the stress of element 4314 is the maximum, and the strain of element 4389 is the maximum. That is, the maximum stress and strain appear in the contact regions of ring chains. During the launch process, the contact regions bear most of impact, regardless of the effects from external factors. Particularly, the maximum stress and strain appear in the contact region of ring chains 3 and 4 (see Fig. 1). As the ring chain 5 is applied on the velocity load, the ring chain 3 is pulled by the ring chain 4 , and the stress concentration with an extremely high value is generated because of the collision, showing that the ring chain stretched by others will generate the maximum stress.

The curves of the maximum stress and strain of elements 4314 and 4389 under different launch speeds are shown in Fig. 3. For the convenience of analyzing the histories of the stress and strain, the time axis is set as the logarithmic coordinates. Figure 3a shows that the overall tendencies of the histories of the stress under different launch speeds are nearly consistent. From 0 to $0.07 \mathrm{~s}$, the stress keeps stable first, and then it increases dramatically. During this process, curves consist well with each other, showing that different launch speeds have slight effects on the stress within a short time. After that, stresses fluctuate swiftly for a period of $0.02 \mathrm{~s}$, and the differences of the amplitudes of stress oscillations are minor. Finally, fluctuations diminish gradually to constants. The above process illustrates that ring chains will strike each other repeatedly until a stable state is reached. When the time is $1 \mathrm{~s}$, ring chains reach a steady state, and the steady stresses under distinct chain speeds of $1.85,5.6$, and $7.8 \mathrm{~m} / \mathrm{min}$ are $748.2,754.5$, and $755.6 \mathrm{MPa}$, showing that the larger launch speed is, the larger the steady stress will be. In terms of the full-load condition, the high launch speed will damage ring chains greatly, reducing its service life to certain extent.

Figure $3 \mathrm{~b}$ shows that the histories of the strains under different launch speeds overlap together. Before $0.014 \mathrm{~s}$, the strain increases slightly, and the fluctuation is extremely minor. During this period, the maximum strain is 0.003 . When the time is $0.014 \mathrm{~s}$, the corresponding stress is $578.4 \mathrm{MPa}$, so the strain is the elastic strain during this period. After $0.014 \mathrm{~s}$, the strain climbs suddenly to $0.1 \mathrm{~mm}$ at $0.022 \mathrm{~s}$, showing that the plastic deformation is generated. In addition, the stress after $0.014 \mathrm{~s}$ exceeds the yield stress, 


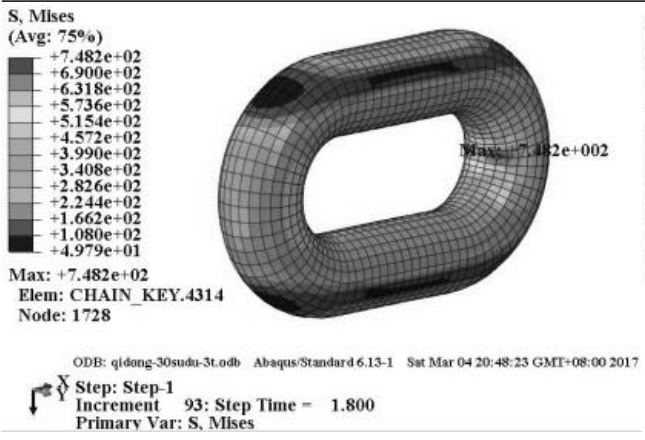

a

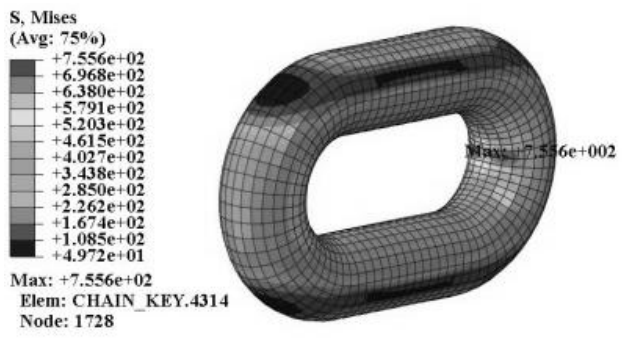

ODB: qidang-130-3t.odb Abaqus/Standard 6.13-1 Sat Mar 04 22:04:48 GMT+08:00 2017

Y $\mathrm{Y}$ Step: Step-1

Increment 102: Step Time $=1.800$

Primary Var: S. Mise

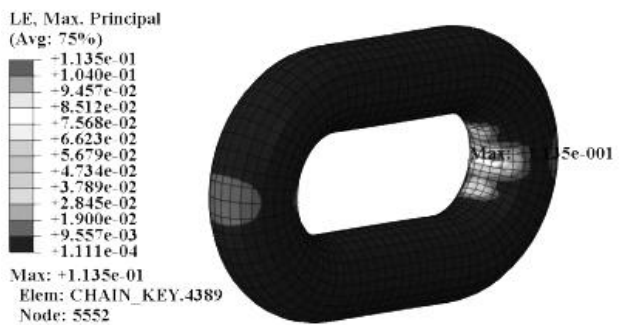

Y Step: Step-1

Increment 105: Step Time - 1.800
Primary Var: LE, Max. Principal

e

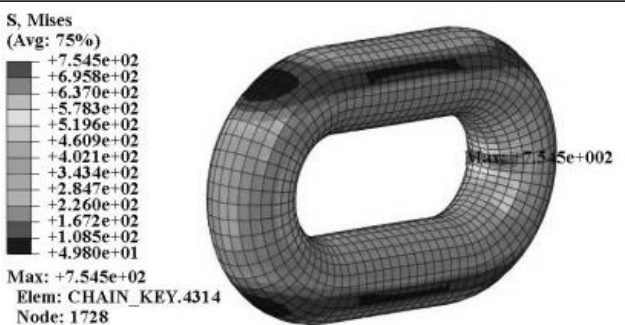

Node: 1728 Y Step: Step-1 Step: Step-1
Increment $105:$ Step Time $=1.800$ Primary Var: S. Mises

b

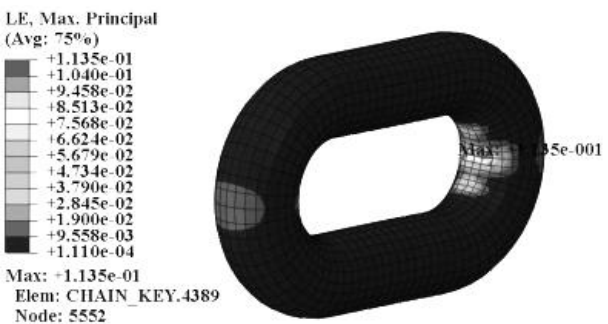

$$
\begin{aligned}
& \text { S. Step: Step-1 } \\
& \text { Increment 93: Step Time - 1.800 } \\
& \text { Primary Var: LE, Max. Principal }
\end{aligned}
$$

ODB: qidnag-30sudu.3tadb Ahaqus Standard6.13-1 Sat Mar 04 20:48:23 GMT+08:00 201?

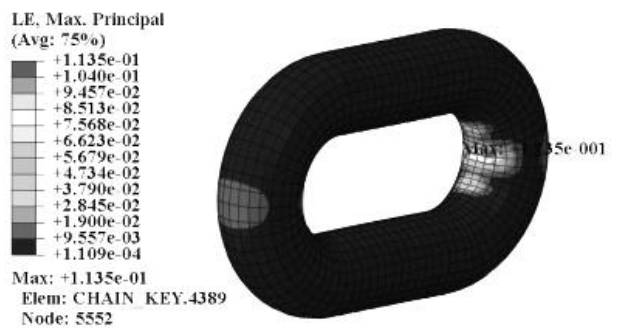
Node: 5552 $f^{X}$ S Step: Step-1 Increment 102: Step Time $=1.800$ Primary Var: LE, Max. Principal

$$
\text { f }
$$

Fig. 2. Contours of stress and strain under different launch speeds: 1.85 (a, d), 5.6 (b, e), $7.8 \mathrm{~m} / \mathrm{min}$ (c, f) stress contour.

supporting the above point of view. From 0.022 to $0.031 \mathrm{~s}$, the strain rises smoothly, and during the same period, the increase of the stress is also slight. Afterwards, the strain goes up to 0.113 , and the strain hardening is produced. Since the plastic deformation is permanent, the strain keeps stable despite of the decrease of the steady stress after $1 \mathrm{~s}$. This is the reason why the strain curves under distinct launch speeds overlap together.

Based on the above analysis, the launch speed affects the stress slightly from 0 to $0.07 \mathrm{~s}$, whereas it will have effects on the steady stress. With the rise in the launch speed, the steady stress will increase. Before $0.07 \mathrm{~s}$, the plastic deformation has already been generated, so the launch speed has slightly effects on the strain after $0.07 \mathrm{~s}$.

Figure 4 shows the trend of 3 kinds of launch speeds are the same. After uniform motion, the contact force reached $20,025 \mathrm{~N}$ at the launch speed of $7.8 \mathrm{~m} / \mathrm{min}$, however, the contact force at the launch speed of 1.85 and $5.6 \mathrm{~m} / \mathrm{min}$ was almost the same, which are 18,771 and $18,785 \mathrm{~N}$, respectively. Thus, with the rise in launch speed, the normal contact 


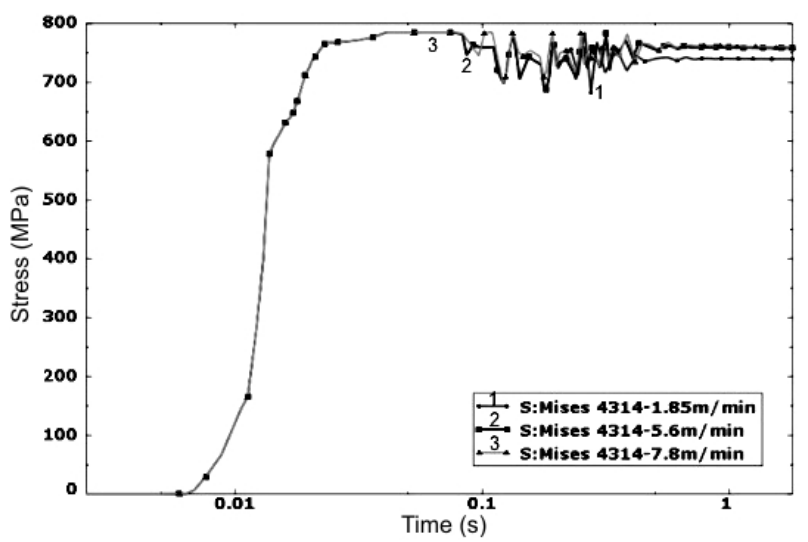

a

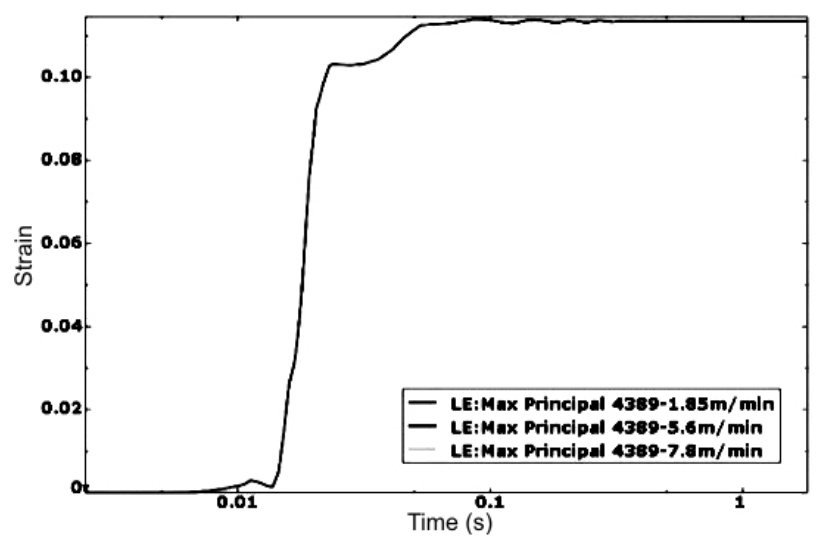

$\mathrm{b}$

Fig. 3. The maximum stress (a) and strain (b) under different launch speeds.

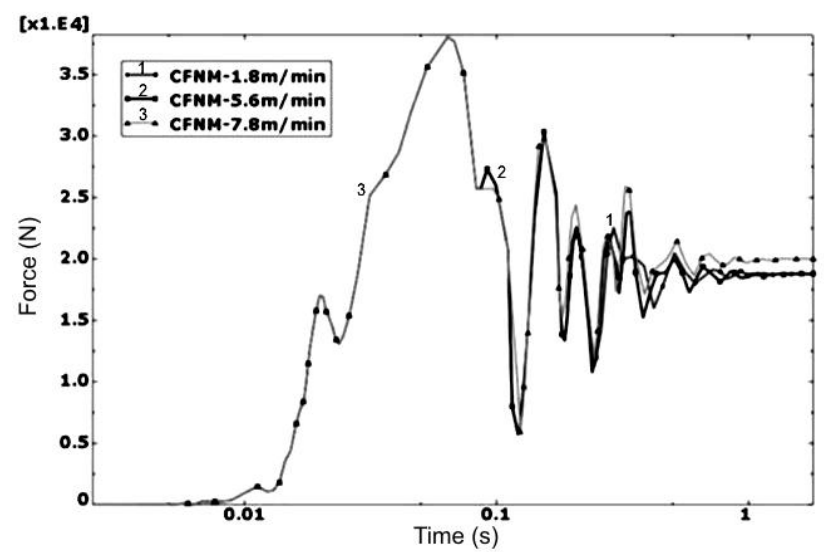

Fig. 4. Normal contact force.

force increases, and causes the chain having greater contact force, so that the chain wear increases, and the chain service life reduces; with the decrease in launch speed, the normal contact force is small, but the running efficiency is not high. Therefore, the starting speed of $5.6 \mathrm{~m} / \mathrm{min}$ can take into account both running efficiency and wear resistance. 
3. Launch Characteristics under Transportation Load. In this section, three sorts of external loads (i.e., 2, 3, and 3.5 ton) are used to simulate the normal, specified, and overload working conditions. Particularly, the semi-ring 1 (see Fig. 1) with the densities of $4.868 \cdot 10^{-1}, 7.3 \cdot 10^{-1}$, and $8.519 \cdot 10^{-1} \mathrm{~kg} / \mathrm{mm}^{3}$ are used to represent these three external loads. The running velocity of the scraper conveyer is $5.6 \mathrm{~m} / \mathrm{min}$. In addition, the accelerative time is $1.5 \mathrm{~s}$, and the even running time is $0.3 \mathrm{~s}$. The obtained stresses and strains under different loads are shown in Fig. 5.
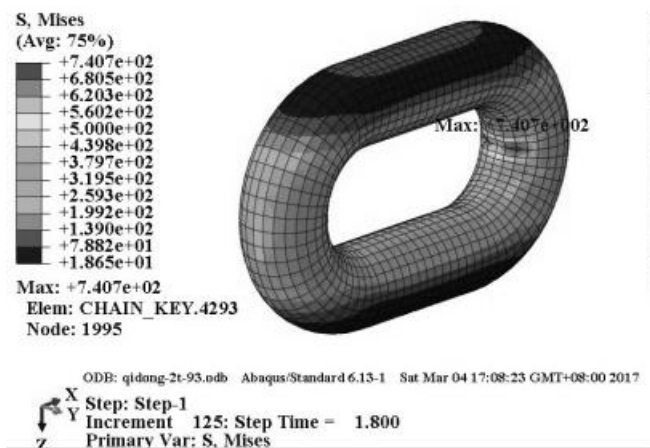

$\mathrm{a}$

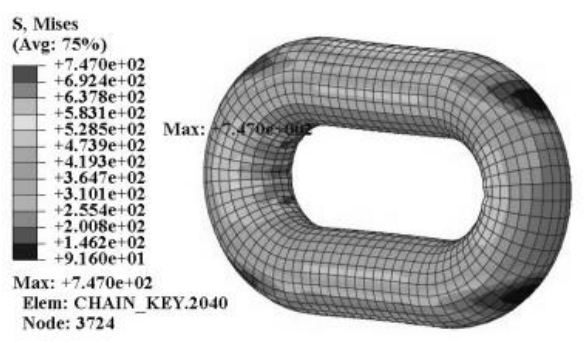

ODB: qidong-3D5t-93. .0dl Abaqus/Standard 6.13-1 Sat Mar 04 17:19:58 GMT+08:00 2017

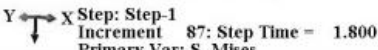

$\mathrm{c}$

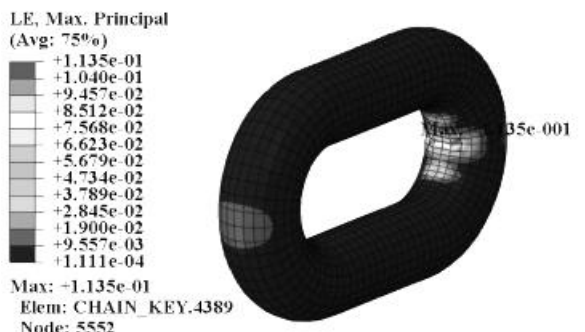

$\mathrm{X}$ ODE: qideng 31 93.odb Abaqus Standard6.13-1 5
Step: Step-1
Increment 105: Step Time $=1.800$
Primary Var: LE. Max. Principal

$\mathrm{e}$

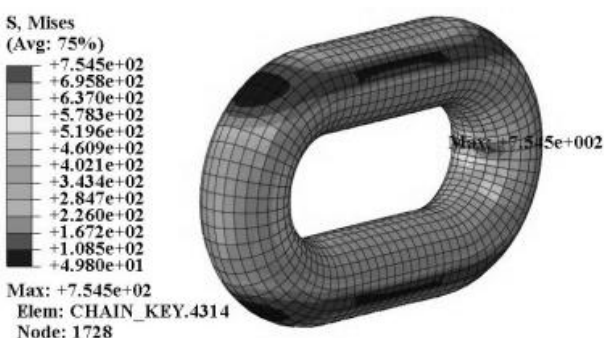

DB: q1dong-3t-93.04b Abaqus/:tandard 6.13-1 Sat Mar 04 17:04:08 GMT+08:00 2017 Step: Step-1

Increment 105: Step Time - 1.800 Primary Var: S. Mises

$\mathrm{b}$

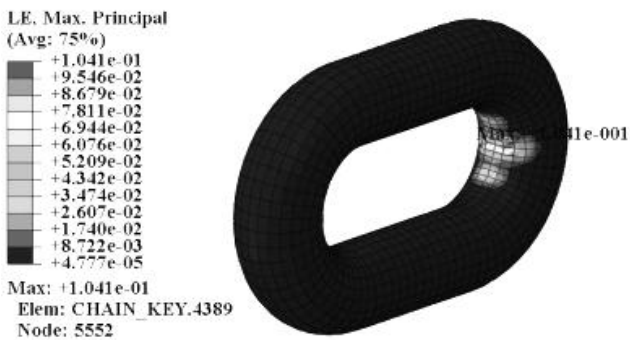

Node: 5532

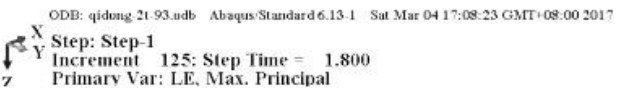

d

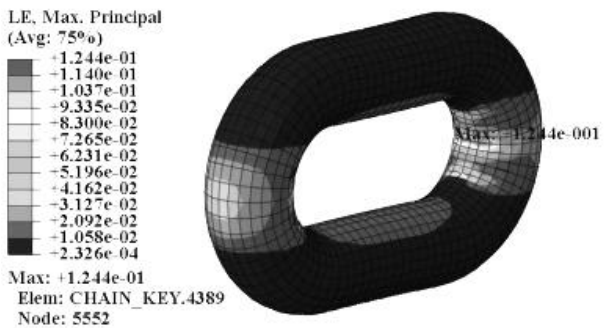

- Step: Step-1
Increment 87; Step Time $=1.800$
Primarv Var: LE, Max. Principal

Fig. 5. Contours of stress $(\mathrm{a}-\mathrm{c})$ and strain $(\mathrm{d}-\mathrm{f})$ under different loads: $2(\mathrm{a}, \mathrm{d}), 3(\mathrm{~b}, \mathrm{e})$, and 3.5 ton $(\mathrm{c}, \mathrm{f})$.

Figure $5 \mathrm{a}-\mathrm{c}$ show that the maximum stresses under the loads of 2 and 3 ton are at the position of the middle area of the inside arc of ring chain 2 (see Fig. 1). When the load of 3.5 ton is applied on ring chains, the position of the maximum stress is at the transition 
region between the inside arc and straight parts of ring chains, and the contact area is increased significantly. That is, when the weight of the transported stuff exceeds the rated load, the apparent stress concentration will appear, causing that the minor contact region is crushed and a larger contact area is produced among ring chains. In addition, because of the excessive load, the position of the maximum stress is changed from the stretched ring chain 3 to the ring chain 2 , which is closer to the ring chain 1 with a mass of 3.5 ton. Figure $5 \mathrm{~d}-\mathrm{f}$ show that the maximum strain elements under different loads are all the element 4389, showing that different loads have no effects on the position of the maximum strain.

Figure 6a shows that when the ring chain bears a larger load, the lower steady stress will be generated. After reaching the steady state, the maximum stresses under the loads of 2,3 , and 3.5 ton are $774.8,758.1$, and $747 \mathrm{MPa}$, respectively. Figure $6 \mathrm{~b}$ shows that with the rise in the load, the steady strain goes up. At $0.016 \mathrm{~s}$, the yield deformation is generated, so ring chains have already been failure when the maximum strain keeps stable. The larger strain will contribute to the larger contact area. Compared with loads, the contact area has significant effects on the stress $[10,11]$. This is the reason why with the rise in the load, there is a decrease in the stress. When the fluctuations under different loads remain stable, the contact force under the load of 3.5 ton is $59,606 \mathrm{~N}$, higher than that under the loads of 2 and 3 ton. Therefore, the normal contact force under the overload condition increases dramatically, which will damage chains seriously or fracture chains suddenly [12-15].

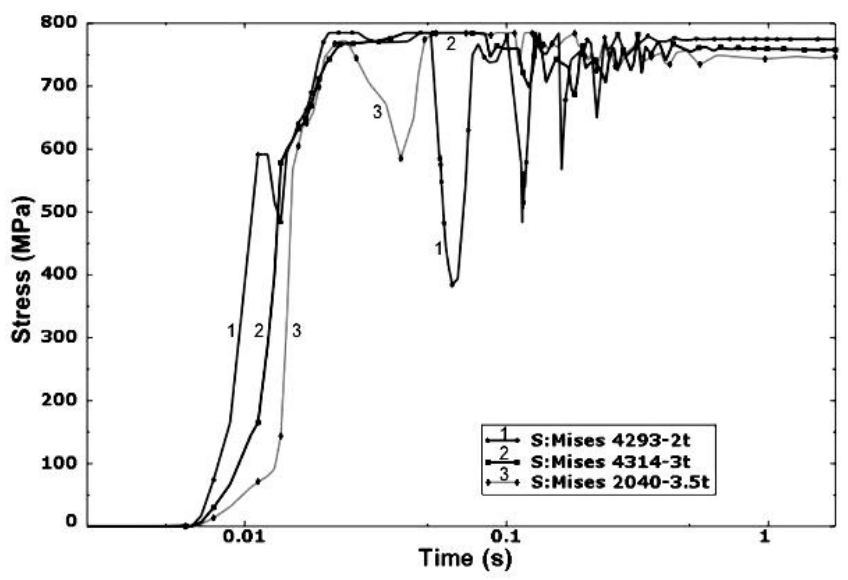

a

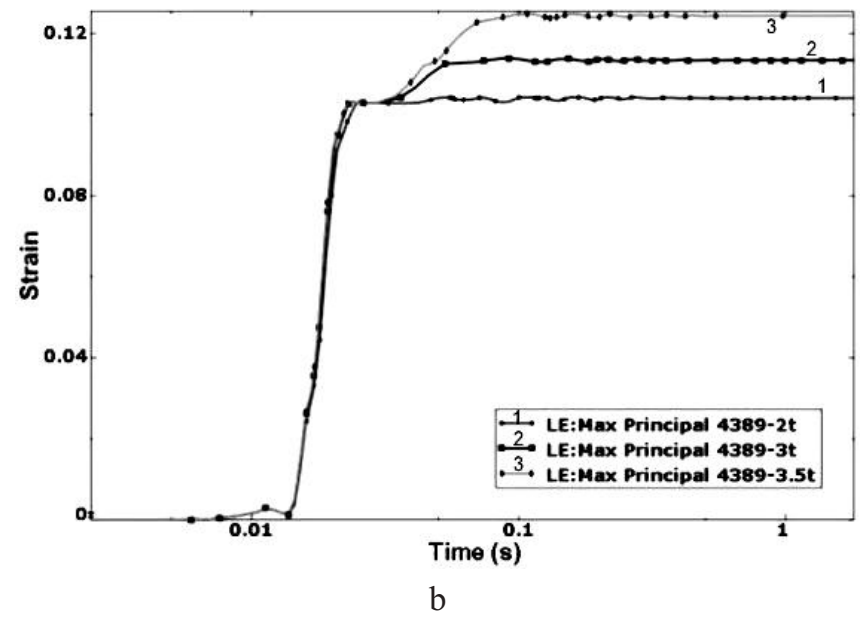

Fig. 6. The maximum stress (a) and strain (b) under different loads. 
4. Experimental Detection and Analysis. To detect the dynamic characteristics of ring chains in real time, the ring chains in the actual scraper conveyer are used. Through the online test method, the detection of tension is fulfilled. During the detection, the force conditions of welded rings are observed, and the middle areas of two straight parts of the welded ring are milled as two plane domains, which can be used to install and protect welding strainmeters. In addition, some grooves are manufactured in the scraper to cover electric wires, and the data receiving device and power source are placed in two cavities, as shown in Fig. 7. The experimental platform used in this study is shown in Fig. 8.

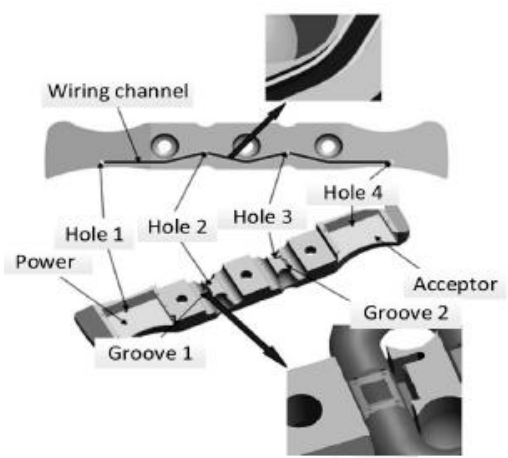

Fig. 7. Installation instruction of instrument.

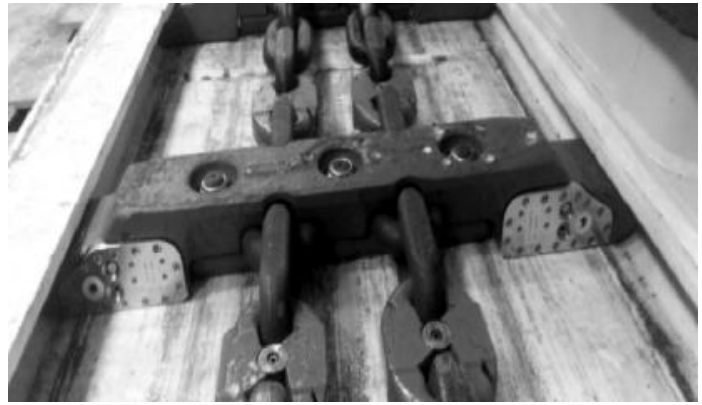

Fig. 8. Experimental platform.

The experiment utilizes the quadratic fitting formula of the stress and load of ring chains given in Eq. (3) to calculate the tension,

$$
F_{1}=-1.6 e^{-5} c h_{1}^{2}-0.2657 c h_{1}-226.7,
$$

where $c h_{1}$ is the measured data (microstrain, $\mu \varepsilon$ ), and $F_{1}$ is the corresponding load, $\mathrm{kN}$.

4.1. Energy Consumption of Ring Chains under No-Load Condition. The strain history within a cycle period under the normal operating condition is shown in Fig. 9. The strains and tensions of special points shown in Fig. 9 are listed in Table 3. In Table 3, numbers 1, 4, and 7 represent the maximum values of transient stresses when the scraper contacts with the sprocket wheel. Number 2 is the detected strain when the sensor is at the position of the lower point of the handpiece, whose tension is $112.73 \mathrm{kN}$. Number 3 is the detected strain when the sensor is at the position of the tail, whose tension is $121.99 \mathrm{kN}$. Obviously, the difference value is $9.26 \mathrm{kN}$ when ring chains run between the lower points of the handpiece and tail. During the operation of the scraper conveyer, the tension of ring chains is caused by the running resistance, so the resistance of the scraper conveyer can be obtained in a special stage according to the computation of the tension. Therefore, the resistance from the lower point of the handpiece to that of the tail is $9.26 \mathrm{kN}$.

The computational formula of the friction between the scraper and chute is given by

$$
F_{f}=v q_{0} L g \cos \theta
$$

where $v$ is the friction coefficient between the scraper and chute, $q_{0}$ is the unit mass of ring chains, $L$ is the working length, $g$ is the acceleration of gravity, $\theta$ is the inclination angle,

$$
W_{z}-v q_{0} L^{2} g \cos \theta=W_{h},
$$

but

$$
W_{z}=F_{z} L,
$$


$\mathrm{T}$ a b 1 e 3

Strains and Tensions of Special Points

\begin{tabular}{|c|c|c|}
\hline Number & Strain $(\mu \varepsilon)$ & Tension $(\mathrm{kN})$ \\
\hline 1 & 2.497 & 279.75 \\
\hline 2 & 1.889 & 142.73 \\
\hline 3 & 1.977 & 151.99 \\
\hline 4 & 2.669 & 292.97 \\
\hline 5 & 1.458 & 115.10 \\
\hline 6 & 1.487 & 124.68 \\
\hline 7 & 1.880 & 210.76 \\
\hline
\end{tabular}

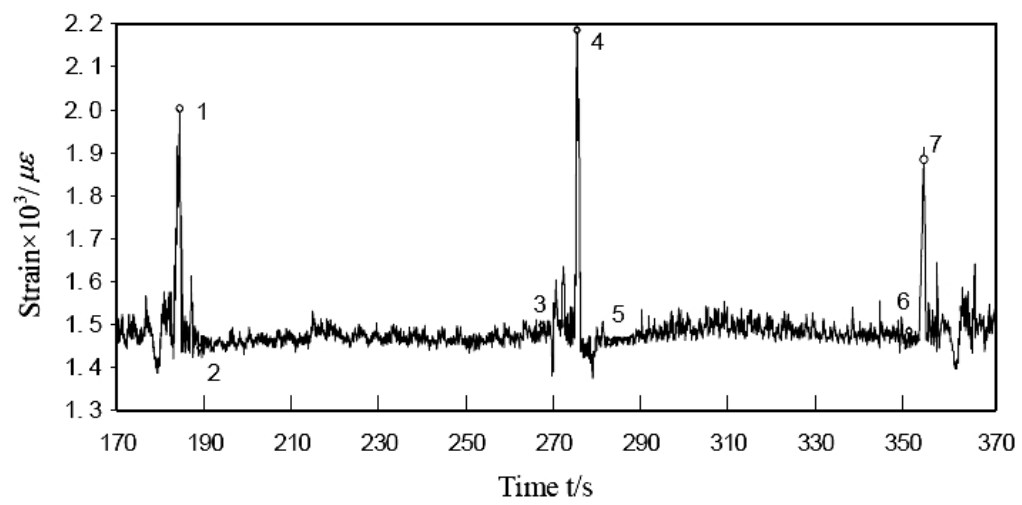

Fig. 9. Strain history within a cycle period.

where $W_{z}$ is total energy consumption caused by the resistance, $\mathrm{J}, F_{z}$ is the total resistance, $\mathrm{N}$, and $W_{h}$ is the energy consumption caused by the friction among ring chains, J.

When the scraper conveyer runs under the no-load condition, the resistance consumption is the main energy consumption. According to the experiment, it is obtained that the total energy consumption caused by the resistance from the lower point of the handpiece to that of the tail is $648.2 \mathrm{~kJ}$. Based on Eqs. (4)-(6), the energy consumption caused by the friction among ring chains is obtained, whose value is $154.28 \mathrm{~kJ}$. The energy consumption caused by the friction among ring chains is $23.8 \%$ of the total energy consumption. In this study, the unit mass of ring chains is $25.2 \mathrm{~kg} / \mathrm{m}$, and the working length is $70 \mathrm{~m}$; the acceleration of gravity is $10 \mathrm{~N} / \mathrm{kg}$.

4.2. Energy Consumption of Ring Chains under Load Condition. When the external load of $3 \mathrm{t}$ is applied on the scraper, the strains and dynamic tensions of detected ring chains are listed in Table 3. Through the experiment, the total resistance caused by the ring chains running from the bottom of the handpiece to the bottom of the tail is obtained. In particular, the total energy consumption caused by the resistance is $858.2 \mathrm{~kJ}$. With the rise in external load, the total energy consumption caused by the resistance increases $210 \mathrm{~kJ}$.

The relationship between the total energy consumption caused by the resistance and load is

$$
W_{h}=7 \cdot 10^{3} F+6.482 \cdot 10^{5},
$$

where $F$ is the external load, ton. 


\section{Conclusions}

1. The steady stresses under distinct chain speeds of $1.85,5.6$, and $7.8 \mathrm{~m} / \mathrm{min}$ are 748.2, 754.5, and 755.6 MPa, determining the optimal chain speed of $5.6 \mathrm{~m} / \mathrm{min}$.

2. The steady stresses under different loads of 2,3 , and 3.5 ton are $774.8,758.1$, and $747 \mathrm{MPa}$, respectively. The normal contact force of ring chains increases swiftly under the overload launch condition, which will damage ring chains greatly and probably generate the fracture failure.

3. The online test method for the ring chain tension is proposed, and experimental analysis is carried out on the experimental platform. The experimental result shows that the load is proportional to the total resistance consumption.

Acknowledgments. This work was financed by the following funds: Ministry of Education PhD Fund: Study on cracking rate of mining ring chain induced by temperature stress corrosion coupling (20132121120011); Key Laboratory of Structural Analysis of Industrial Equipment Open Fund (Dalian University of Technology): Research on reliability and life design of chain transmission system of scraper conveyor (GZ1402); State Key Laboratory of Mechanical Transmission Open Fund (Chongqing University): The theory and key technology of high efficiency transmission of scraper conveyor chain (SKLMT-KFKT201515); Liaoning Natural Science Fund Project (20161324): Study on multiinformation fusion recognition of coal rock interface based on physical and cutting characteristics.

\section{Резюме}

Досліджено механічні характеристики високоміцного кільцевого ланцюга транспортного обладнання за різних робочих параметрів та зв'язане $з$ цим енергоспоживання. Динамічна контактна задача моделюється за допомогою скінченноелементного пакета ABAQUS для різних транспортних навантажень і швидкостей руху ланцюга 3 подальшою експериментальною верифікацією отриманих результатів. Установлено, що оптимальне функціонування ланцюга відповідає швидкості руху 5,65 м/хв., за якої деформація і напруга є стабільними. У режимі перевантаження нормальна напруга збільшується багаторазово, що призводить до суттєвого пошкодження ланцюга. Показано, що при холостому режимі роботи ланцюга $23,8 \%$ споживаної енергії витрачається на подолання сил тертя. Із підвищенням робочого навантаження відмічається лінійне зростання споживаної енергії. Отримані динамічні механічні характеристики ланцюга дозволяють уточнити прогноз його довговічності в умовах експлуатації та удосконалити схему енергоспоживання електромоторів.

1. Q. Zhang, H. J. Wang, T. Guo, and Y. F. Fu, "Dynamic characteristics and impact damage of mining scrapers under different working conditions and chain speeds," $J$. Vibr. Shock, 35, No. 24, 51-58 (2016).

2. Q. Zhang, H. J. Wang, and T. Guo, "Fatigue damage of v-lock chain ring under random load," Pol. Marit. Res., 23, 4-9 (2016).

3. Q. Zhang and S. J. Li, "Topological optimization of pick structure based on LS-DYNA,” Disaster Adv., 5, No. 4, 187-193 (2012).

4. B. Y. He, Y. H. Sun, R. Nie, and G. P. Li, "Dynamic behaviour analysis on the ring chain transmission system of an armoured face conveyor," J. Mech. Eng., No. 17, 50-56 (2012).

5. J. Mao, D. S. Zhang, and J. G. Shi, "Simulation research of tension automatic control system of scraper conveyor," J. Syst. Simul., No. 16, 4474-4476, 4484 (2008). 
6. L. Shi and Y. Gao, "Experimental study of chain fatigue life," J. Taiyuan Univ. Technol., No. 03, 270-272, 299 (2005).

7. H. Xue, L. Liu, Z. M. Yang, et al., "Effect of low temperature and strain rate on impact property of mining chain," J. Xi'an Univ. Sci. Technol., No. 03, 343-346, 362 (2011).

8. Q. Zhang, M. J. Xu, and N. Hu, "Study on fatigue life of plow bit under different planning parameters," Strength Mater., 46, No. 2, 262-269 (2014).

9. H. J. Wang, Q. Zhang, and F. Xie, "Dynamic tension test and intelligent coordinated control system of a heavy scraper conveyor," IET Sci. Meas. Technol., 11, No. 7, 871-877 (2017).

10. X. W. Dang, X. Ma, "Influence of asperity collision on contact stress and strain," Tribology, 37, No. 1, 11-18 (2017).

11. M. Wang, Z. R. Li, and X. H. Ma, "Influence of sphere contact area on stress of T-shape bolt in fastener," Railway Eng., No. 12, 102-104 (2016).

12. Q. Zhang, H. J. Wang, J. Mao, et al., "Self-powered tension testing system for scraper conveyor based on piezoelectric vibration energy harvested," Chinese J. Sensor. Actuat., 28, No. 9, 1335-1340 (2015).

13. Q. Zhang, H. J. Wang, Y. F. Fu, and J. Gong, "Mechanical property and fatigue life prediction of sprocketing scraper conveyor," J. Mech. Strength, 37, No. 2, 328-336 (2015).

14. Q. J. Luo, "Analysis of fatigue strength round link chain for mine use," J. China Coal Soc., 22, No. 4, 95-99 (1997).

15. Y. F. Zhao, "The dynamic research on hoisting mechanism of crane based on virtual prototype technology,” Shanghai Univ. Eng. Sci. (2015). 